\title{
Tanulmányok
}

\section{AZ ÉGHAJLATVÁLTOZÁSRÓL 12 FEJEZETBEN}

ON CLIMATE CHANGE IN 12 SECTIONS

\section{MIKA JÁNOS}

Eszterházy Károly Egyetem Földrajz- és Környezettudományi Intézet, Eger

mika.janos@uni-eszterhazy.hu

\begin{abstract}
Key aspects of climate change are comprehended for teachers of geography. Scientific background of the paper is the last IPCC Report (IPCC AR5 2013). The sections of the paper are: what the data prove; what the climate models attest; what the scenarios foresee; what to do with all of these.
\end{abstract}

Keywords: observed changes, forcing factors, projections, adaptation, mitigation

\section{Bevezetés}

A tanulmány 4 fejezet tekinti át az éghajlatváltozás kérdéseit. Kevés tudományos kérdésről látnak, hallanak és olvasnak annyi (igaz és téves) információt tanítványaink, mint éppen erről. Fontos, hogy az ö tanáraik is tájékozottak legyenek minderről, még ha a média nem is segíti őket ebben. Írásunk ehhez kíván támogatást nyújtani. A leírtak nagyrészt az Éghajlatváltozási Kormányközi Testület legutóbbi jelentésén (IPCC AR5 2013) alapulnak.

\section{Amit az adatok bizonyítanak}

\section{Miben mutatkozik meg a globális felmelegedés?}

Az elmúlt mintegy száz esztendőben kb. $1{ }^{\circ} \mathrm{C}$-kal emelkedett a Föld átlaghőmérséklete (1. ábra). A változás nagyobb része az utolsó ötven esztendőre esik, de már az 19101940-es évek között is történt mintegy $0,3{ }^{\circ} \mathrm{C}$-nyi melegedés. A két érték között a földi átlaghőmérséklet stagnált, ezen belül az északi félgömb átlaghőmérséklete még egy picit vissza is esett. Sajnos ez a változás nemcsak a felszínközeli léghőmérsékletekben nyilvánul meg, hanem az utóbbi fél évszázadban a légkör alsó $10 \mathrm{~km}$-es rétegének, a troposzférának teljes vastagságában, valamint a $10 \mathrm{~km}$ fölötti ún. sztratoszférában is jelentkezik, de ott lehűlésként, ami természetes dolog, mert az a többletenergia, amit az üvegházhatású gázok elnyelnek, nem tudja már melegíteni ezt a réteget. 
A tengervíz hőmérséklete is hasonló arányban mutatja e változásokat, nagyjából ugyanolyan mértékben, mint a léghőmérséklet. A szilárd jég (a krioszféra) is változott az elmúlt évtizedek során. A tengeri jég kiterjedése - elsősorban a nyári időszakban - nagyon erősen visszahúzódott. Nagyjából az 1970-es évek eleje óta láthatjuk műholdról, hogy mekkora ez a kiterjedés, és bizony óriási mértékben összehúzódott már eddig is a jégtakaró: átlagosan 15\%-kal, de egy-egy évben akár 40\%-kal is. A téli félévre a jég visszafagy, tehát nem kell tartani a tengeri jég teljes eltủnésétől. A hegyvidéki gleccserek majdnem mindenhol jelentősen zsugorodtak. Csak ott ellentétes irányú a folyamat, ahol a csapadéktöbblet erősebben táplálja a gleccsereket, mint ahogyan a meleg csökkenti a tömegüket.

A legalább az 1970-es évek közepétől tapasztalt egyenletes felmelegedést nemrég átmenetileg megszakította az ún. globális melegedési hiány (angolul global warming hiatus). Ezen azt a viszonylag rövid ideig (kb. 2002 és 2013 között) fennállt tapasztalatot értjük, miszerint ekkor a felszín közeli léghőmérséklet alig emelkedett, és bő tíz éven át egyértelműen a várt érték alatt maradt. A melegedés elmaradását elsősorban a déli félgömb óceánjainak a korábbinál sokkal gyorsabb hőelnyelésével, illetve a naptevékenység gyengébb, a vulkánosságnak pedig erősebb jellegével próbálták magyarázni (részletesebben l. MiкA J. 2014). A légkör melegedésének elmaradása nem jelentette azt, hogy ne nőtt volna továbbra is egyenletesen a teljes éghajlati rendszer (légkör, óceán, szárazföld, krioszféra, bioszféra) energiatartalma. Belső ingadozás volt elsősorban a szférák között, amiket azonban a globális klímamodellek nem láttak elöre, sőt utólag

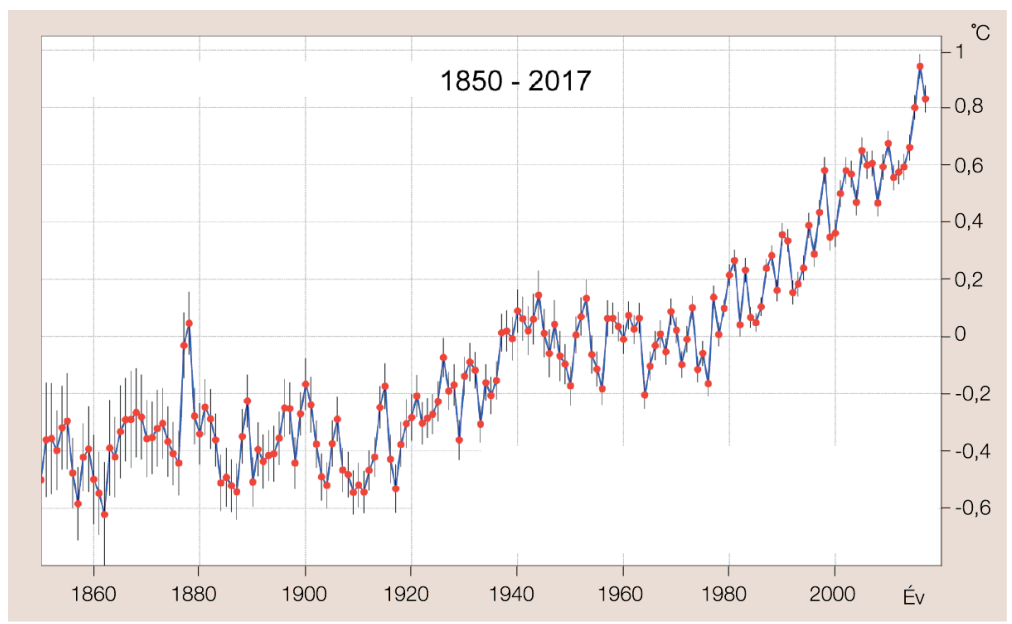

1. ábra. A globális átlaghőmérséklet alakulása a globális fedettség kezdetétől 2017-ig (forrás: http:// berkeleyearth.org/global-temperatures-2017/) 
sem szimuláltak megfelelően. A melegedés elmaradása önmagában nem vonja ugyan kétségbe a sok évtizedes felmelegedés tendenciáit és az okok legalább részben emberi eredetét. Ugyanakkor arra figyelmeztet, hogy még nem tudunk mindent az éghajlatváltozás folyamatairól. Érhetnek még bennünket meglepetések a folyamat sebességének a várttól való - akár mindkét irányú - eltérése formájában.

Sajnos - mindent egybevetve - az, hogy bolygónk melegszik, nehezen vonható kétségbe. Az viszont már egy másik kérdés - amire tanulmányunk későbbi részében térünk vissza -, mi bizonyítja azt, hogy ezekért a változásokért valóban az emberi tevékenység a felelős?

\section{Miben más a mostani, mint a korábbi változások?}

Az éghajlatváltozás fontosságát tagadók egyik legfőbb érve az, hogy a földtörténet során máskor is volt lényegesen melegebb a Földön, sőt az 5 milliárd esztendő mintegy $90 \%$-ában nem is borította sohasem jég a felszínt. Voltak azonban jégkorszakok, amikor a Kárpátok vidékén is jég volt télen-nyáron, ilyenkor a Föld átlaghőmérséklete legalább 4-5 ${ }^{\circ} \mathrm{C}$-kal alacsonyabb volt, mint a mostani érték. Ám ezek a különbségek nem évtizedek vagy néhány évszázad alatt alakultak ki, hanem évtízezrek, esetleg évmilliók alatt. A mostani változások tehát egy-két nagyságrenddel gyorsabbak, mint a korábbiak. A 2. ábrán a (logaritmikus skálán ábrázolt) idő függvényében a Föld felszín közeli átlaghőmérsékletének alakulása látható az elmúlt százmillió évben. Ezen megfigyelhető, hogy a sok tízmillió éves, csillagászati okból kialakult jégkorszakokat leszámítva a Föld hőmérséklete mindvégig egy $\pm 5^{\circ} \mathrm{C}$-os tartományon belül ingadozott, jelenleg azonban e sáv felső határa felé közelit. Ugyancsak látható az ábráról, hogy az eddig természetes okból végbement változások az utolsó tízezer évben nem haladták meg a $\pm 1{ }^{\circ} \mathrm{C}$-ot. Tehát az emberi behatás rövidesen meghaladja majd az elmúlt tízezer évben tapasztalt természetes ingadozást és közelíthet a tízmillió éves léptékekhez.

\section{Amit a klímamodellek tanúsítanak}

\section{Milyen természetes és antropogén okai lehetnek a változásnak?}

Az elmúlt száz esztendő körülbelül $1^{\circ} \mathrm{C}$-os melegedéséért nagy valószínűséggel a légkör üvegházhatásának erősödése a fö felelős. Az üvegházhatás abban áll, hogy a Nap sugarait a légkör összetevői nagyrészt beengedik a felszínre, ami hőátadással melegíti a levegőt. 


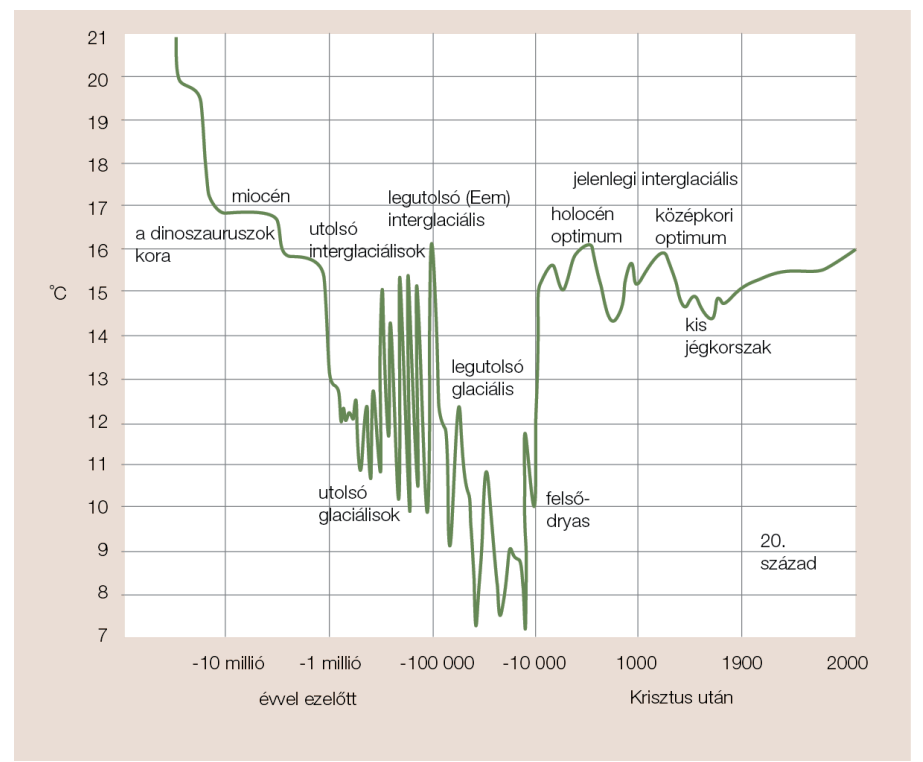

2. ábra. A Föld becsült átlaghömérsékletének alakulása az elmúlt 100 millió évben (forrás: az Ausztrál Meteorológiai Szolgálat oktatási anyaga, 22. ábra: http://www.bom.gov.au/info/climate/ change/gallery/1.shtml)

Viszont a 4 mikrométernél hosszabb, úgynevezett hosszúhullámú sugarak egy részét ezek az üvegházhatású gázok és a vízgőz elnyelik. Tehát minél több üvegházhatású gáz van a levegőben, annál kisebb arányát tudja kibocsátani a légkör a felszínről kiinduló energiának. Azaz sajátos hőcsapdaként müködik, amit a Föld - mint bolygó - csak úgy tud kiegyenlíteni, hogy magasabb hőmérsékleten sugároz ki, és ezáltal tud pontosan annyi energia eltávozni a légkör külső határán keresztül, mint e gázok felszaporodása előtt.

Ilyen üvegházhatású gáz a szén-dioxid $\left(\mathrm{CO}_{2}\right)$, a metán $\left(\mathrm{CH}_{4}\right)$ és a dinitrogén-oxid $\left(\mathrm{N}_{2} \mathrm{O}\right)$. A halogénezett szénhidrogének, azaz freonok, halonok (amelyek száma meghaladja a kétszázat) is üvegházhatású gázok. Mindezek mennyisége kimutathatóan nő a légkörben, tehát a szén-dioxidé mintegy 40\%-kal, a metáné több mint megkétszereződött a természetes állapotok kezdete óta, a dinitrogén-oxidé pedig mintegy 20\%-kal nőtt. A halogénezett szénhidrogének esetében végtelen növekedésről kell szólnunk, mivel természetes forrásai ezeknek az anyagoknak nem ismeretesek.

Az üvegházhatású gázokon kívül éghajlatunkat még több más természetes és mesterséges folyamat is alakítja. A mesterséges hatások közül elsősorban az aeroszol mennyiségének megnövekedését tudjuk említeni. A légkör aeroszolkészlete folyékony 
és szilárd alkotórészekből áll, amelyek kisebbek az esőcseppeknél. Elsősorban a szulfát-aeroszolok ilyenek, amelyek mennyisége az 1980-as esztendőkig az üvegházhatású gázokkal párhuzamosan emelkedett, azonban ekkor több egyezmény, valamint a fütési technológia változásának hatására a fejlett országokban visszaesett. Ugyanakkor a Föld fejlődő térségeiben ez a csökkenés még nem tapasztalható. A légkör összetétele úgy alakult ebből a szempontból, hogy az 1960-as és az 1990-es évek között homályosabbá vált a légkör, majd az 1990-es évek óta egy kicsit átlátszóbbá. A homályosabb légkör fékezi az üvegházhatású gázok okozta melegedést, amikor viszont csökken a homályosság, akkor ez a változás erősíti a melegedést. Az aeroszoloknak kétféle hatása van. A fentebb hivatkozott közvetlen hatása abban áll, hogy a napsugarakat szórja, nem engedi le a felszínre, ezáltal nem képes olyan mértékben melegíteni a légkört, az indirekt hatása pedig az, hogy a felhőcseppek vízmennyisége megnő, és kisebb cseppek alakulnak ki, amelyek jobban, erőteljesebben verik vissza a napsugarakat a világür felé, mint a nagyobb cseppek. Az elmúlt fél évszázad melegedéséért tehát nagy valószínűséggel az üvegházhatású gázok fokozódó légköri aránya a felelös. Az elmúlt 250 évben a szén-dioxid $1,7 \mathrm{~W} / \mathrm{m}^{2}$-rel növelte a sugárzási mérleget, amihez a többi üvegházgáz további $1,6 \mathrm{~W} / \mathrm{m}^{2}-t$ tett hozzá. Az aeroszol-koncentráció ezt $-1,1 \mathrm{~W} / \mathrm{m}^{2}$ erejéig tudta ellensúlyozni. Így bolygónknak mára $2,3 \mathrm{~W} / \mathrm{m}^{2}$ többlettől kellene megszabadulnia.

A természetes hatások közül a vulkánkitörések és a naptevékenység ingadozása emelhető ki. A kén-dioxidban gazdag erős vulkánkitörések 1-3 éven át csökkenthetik a Föld átlaghőmérsékletét. A naptevékenység nagyon csekély mértékben ingadozik 11, illetve 22 éves ciklusokkal. Ezek a természetes hatások rövidebb ideig tartanak és gyengébbek az emberi eredetűeknél. Egyik természetes tényezőnél sincs tudományos alapunk annak feltételezésére, hogy bármelyikük sokkal erősebbé válna, mint amilyen eddig volt.

\section{Mi bizonyítja, hogy a változásokért az emberi tevékenység a felelős?}

Ha a tapasztalt koncentrációváltozást és minden ismert éghajlati kényszert betápláljuk az éghajlati modellekbe, akkor reprodukálni tudjuk a 20. század második felének felmelegedését. Ezek a teljes Föld éghajlati folyamatait szimuláló modellek a tömeg, az energia és az impulzus megmaradását leíró parciális differenciálegyenleteken alapulnak, egy-egy kutatóhelyen 100-200 szakember és informatikus erőfeszítését megtestesítő szuper-számítógépes rendszerekkel (1. IPCC AR5 2013 9. fejezet; MIKA J. 2011 3. fejezet) készülnek. A modellszámítások nyomán 95\%-os valószínűséggel állíthatjuk, hogy a 20. század 
közepén kezdődött melegedés legalább feléért az emberi tevékenység a felelös. Ennek fő bizonyítéka az, hogy ha e folyamatokat, valamint az összes többi ismert és előbbiekben felsorolt természetes és antropogén hatást betápláljuk a számítógépes modellekbe, akkor ezekkel a modellekkel reprodukálni tudjuk az elmúlt száz esztendő történéseit (3. ábra); de ha eltávolítjuk a modellekböl az antropogén tényezőket és csak a természetes tényezőkkel számolunk, akkor az utóbbi ötven esztendő melegedése egyáltalán nem mutatható ki.

Két óriási hibát kellene a világ tudományosságának elkövetnie ahhoz, hogy ne az legyen a helyes következtetés, hogy az ember okozza a változást. Az egyik hiba az, hogy nagyon túlbecsüljük az üvegházhatású gázok szerepét, és az valójában sokkal kisebb a számítottnál. A másik hiba ezzel párhuzamosan az, hogy valami mégiscsak okozza a változást, amiről nem vettünk tudomást. Ennek a két nagy hibának a valószínűsége nem nulla, de az Éghajlatváltozási Kormányközi Testület szakértői becslése szerint kisebb, mint 5\%. Tehát több mint 95\% annak a valószínűsége, hogy a változásban szerepet játszott az ember hatása.

\section{Amit a forgatókönyvek előrevetítenek}

\section{Milyen globális éghajlatváltozás várható, lehetnek-e meglepetések?}

$\mathrm{Az}$ üvegházhatás erősödését feltételező reprezentatív koncentrációpályák szerint 2100-ra az eddigi $2,3 \mathrm{~W} / \mathrm{m}^{2}$-ről 4,5-8,5 W/m²-re nőhet a légköri üvegházhatás mesterséges többlete. A legoptimistább, csak $2,6 \mathrm{~W} / \mathrm{m}^{2}$ többletet feltételező változat esetén 2100-ra csaknem visszaáll a mai állapot. A globális éghajlati modellek tanúsága szerint az első három forgatókönyv megvalósulása esetén a Föld hőmérséklete $1-5{ }^{\circ} \mathrm{C}$-kal
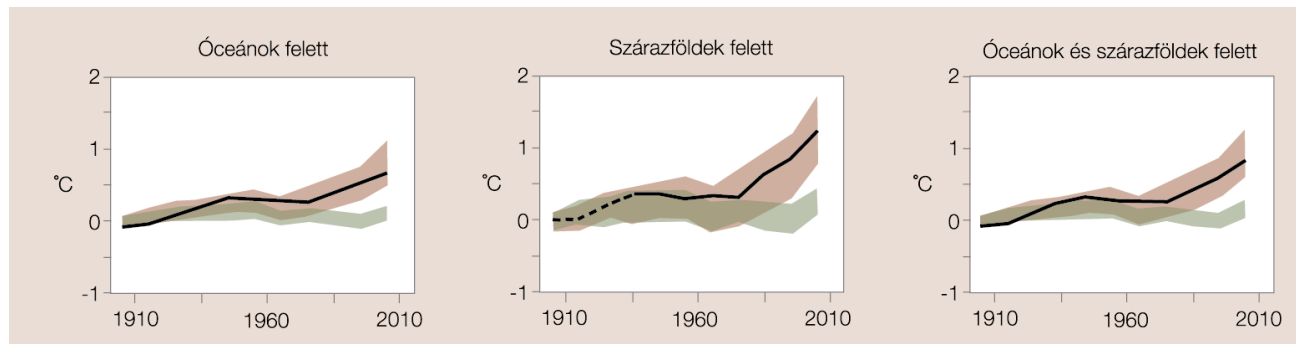

3. ábra. A megfigyelt simitott globális átlagos léghömérséklet alakulása (fekete vonal), szembesítve a csak természetes hatásokkal (kék sáv), illetve az antropogén hatásokat is figyelembe (piros sáv) modellszimulációkkal. (Forrás: IPCC AR5 2013. 10.21 ábra) 
emelkedhet századunk végére a 20. század utolsó két évtizedéhez képest. Az optimista forgatókönyvből csak $0,3-1{ }^{\circ} \mathrm{C}$ melegedés következik (4. ábra). Megállapíthatjuk, hogy a legmeredekebb RCP8.5 forgatókönyv kissé pesszimistább a korábbi (IPCC 2007) második legradikálisabb - A1 forgatókönyvnél, míg a közepes RCP6.0 és RCP4.5 forgatókönyvek felülről, illetve alulról közelítik a korábbi legenyhébb B1 forgatókönyvet. A különlegesen optimista RCP2.6 forgatókönyvhöz hasonló lehetőség még nem szerepelt a korábbi IPCC jelentésekben.

A fenti elörejelzések tanúsága szerint - eltekintve az igen optimista RCP2.6 forgatókönyvtől - a Föld átlaghőmérséklete $1^{\circ} \mathrm{C}$ és $5{ }^{\circ} \mathrm{C}$ közötti mértékben melegedhet századunk végére a 20. század utolsó két évtizedéhez képest. Miből adódik ez a nagy különbség? Az egyik ok az, hogy nem tudjuk pontosan, miképpen alakul az üvegházhatású gázok kibocsátása a jövőben, hiszen ez nagyban függ többek között a népesség változásától, az energiaigények alakulásától, a környezettudatos, vagy éppen azzal ellentétes iparfejlődéstől és a Föld különböző térségei közötti egyenlőség vagy egyenlőtlenség alakulásától. A másik bizonytalansági tényező az éghajlati rendszer érzékenysége, amit ma körülbelül 50\%-os hibával tudunk csak becsülni. Azonban, bármekkora is ez a bizonytalanság, arra nincs esély, hogy nulla változás legyen a következmény. Söt annyira nincsen, hogy ha a holnapi naptól állandó értéken tudnánk tartani a szén-dioxid és egyéb üvegházhatású gázok mennyiségét a légkörben, egy $0,3-0,4^{\circ} \mathrm{C}$-os melegedés, egy úgynevezett „bünteto"” melegedés akkor is bekövetkezne, mert a korábbi évtizedekben megnövelt üvegházhatású gázok elöször az óceánt melegítik, és csak utána adja át az óceán ennek egy részét a légkörnek.
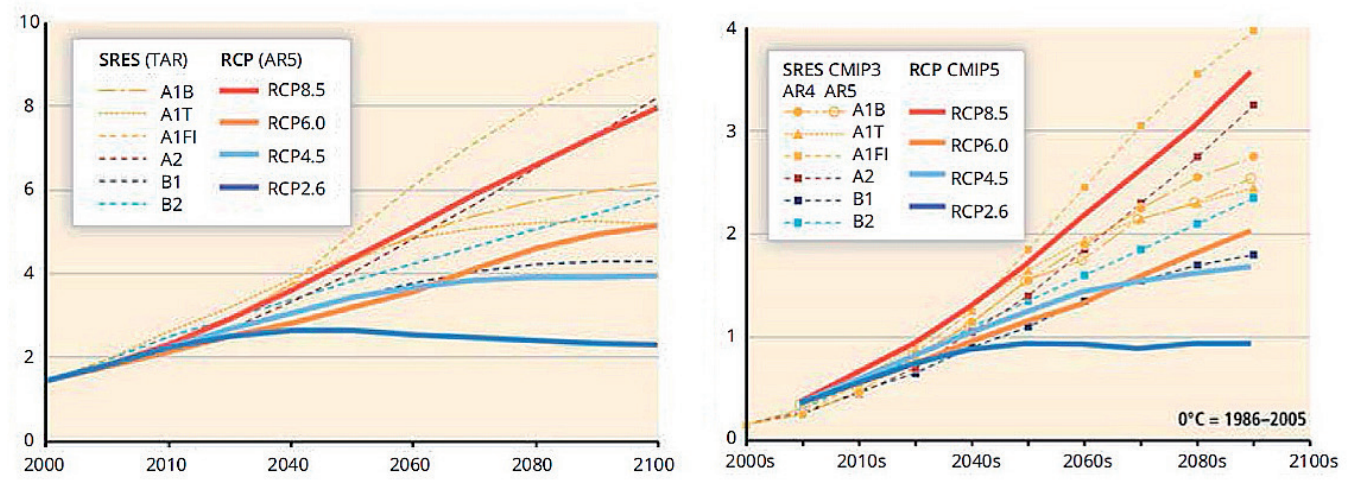

4. ábra. Elörejelzett változások a sugárzási kényszerben (balra) és a globális átlaghömérsékletben (jobbra) a 21. században a különbözö reprezentatív forgatókönyvek alapján (forrás: IPCC, 2014. 1.4. ábra) 
Biztos-e, hogy ilyen „időben sima” alakulása lehet bolygónk éghajlatának? 2004 elején találkozott a világ az ún. Pentagon-jelentéssel, amelyik azt vette számba, hogy mi történhet a Földön, ha a melegedés egy későbbi pontján jégkorszakba csap át a bolygónk éghajlata. Ha ugyanis az óceáni szállítószalag leáll, akkor nem fog hőt szállítani az északi területekre, és ez a hőhiány ott megnövelheti a jégtakaró kiterjedését. Ennek a félelemnek az az alapja, hogy 10000 évvel ezelőttől a még korábbi időszakokig, közel százezer éven át nagyon nagy ingadozások voltak tapasztalhatók a tengerfenéki megfigyelések, az óceáni mészházakból rekonstruált hőmérsékletek alapján. Olyankor, amikor hirtelen éghajlatváltozás történt, minőségileg alakult át az óceáni cirkuláció.

Nem tudjuk, hogy a hőmérsékletváltozás váltotta-e ki az óceáni cirkuláció változását, vagy esetleg fordítva. Ez utóbbi eset az is nagy probléma, mert ez később is fenyegetheti a Földünket. Újabb számítások szerint annyiban megnyugodhatunk, hogyha le is áll teljes egészében az óceáni cirkuláció, akkor sem lesz ennek jégkorszak a következménye. A sark közeli területeket uraló hideg ellenére a Föld egészét tekintve a szén-dioxid-többlet melegítő hatása erősebb lesz, mint a szállítószalag leállása miatti lehủlés. Tehát a jégkorszakkal, mint várható jövőképpel valószínüleg nem kell számolnunk.

A fenti minőségi ugrás mellett néhány más kritikus billenőpontot is jelez az 1. táblázat adatsora. Kitünik belőle, hogy $3-5^{\circ} \mathrm{C}$-nyi változás esetén a nyugat-antarktiszi jégtömb olvadása és az óceáni szállítószalag legyengülése drámai tengerszint-emelkedéssel, illetve az időjárás átrendeződésével fenyeget. Az Antarktisz nyugati részén a jégtakaró - ami a kontinentális talapzattal a tengervíz szintje alatt érintkezik - megolvadhat, besodródhat, és ez a folyamat 5 méterrel emelheti a tengervíz szintjét. Látható az is, hogy az északi óceán jegének nyári visszahúzódását már aligha tudjuk megakadályozni. Végül, a grönlandi jégsapka olvadásának perspektívája azt is elörevetíti, hogy nem elég

\begin{tabular}{l|lll}
\hline Érzékeny térség & Globális küszöb & A változás időléptéke & Következmény \\
\hline $\begin{array}{l}\text { Arktikus jégtakaró, nyáron } \\
\text { Grönlandi jéghátság }\end{array}$ & $+0,5-2,0{ }^{\circ} \mathrm{C}$ & $\sim 10$ év (gyors) & $\begin{array}{l}\text { többletmelegedés } \\
2-7 \text { méteres vízszintemel- } \\
\text { kedés }\end{array}$ \\
$\begin{array}{l}\text { Nyugat-antarktiszi self-jég- } \\
\text { tömb }\end{array}$ & $+1,0-2,0{ }^{\circ} \mathrm{C}$ & $\sim 300$ év (tartós) & $\begin{array}{l}5 \text { m-es vízszintemelkedés } \\
\text { Észak-atlanti szállítószalag } \\
\text { gyengül }\end{array}$ \\
\hline
\end{tabular}

1. táblázat. A földi éghajlat azon kritikus billenőpontjai, amelyet elérve a melegedés már kritikus minőségi ugrást szenvedhet (Lenton et al. 2008 nyomán) 
megállítani a változást, hanem később vissza is kell hüteni, mert különben a grönlandi jég makacsul tovább olvad és emeli a tengerszintet. A táblázatban összefoglalt globális ugrások mellett még egy tucat regionális léptékű kritikus ugrást ismerünk, például az El Niño-La Niña oszcillációval kapcsolatban.

\section{Hogyan alakulnak a regionális változások és a szélsöségek?}

Természetesen az éghajlatváltozásnak nem a földi átlaghőmérséklet változása a lényege, hanem az, hogy az egyes térségekben hogyan alakulnak a legfontosabb meteorológiai elemek, elsősorban hőmérséklet és a csapadék mennyisége. Az 5. ábra az évi átlaghőmérséklet és az éves csapadékösszeg várható változásait mutatja be $1^{\circ} \mathrm{C}$ globális melegedésre vonatkoztatva. Nos, a hőmérséklet változása a poláris térségben a legerősebb, többszörösen meghaladhatja a földi átlag változását, ugyanakkor az egyenlítői területeken sokkal kisebb a változás. A csapadékváltozás még különlegesebb. Az Egyenlítő térségében - ahol eddig is bőséges volt a csapadék - egy kicsit nő a mennyisége, a monszunterületeken is, sőt az $50^{\circ}$ földrajzi szélességtől északra ugyancsak nő a csapadék éves hozama. Ugyanakkor mindenhol máshol (így például hazánkban és a tölünk délebbi területeken) viszont csökken, sokfelé jelentősen csökken a csapadékhozam.

Azt biztosan állíthatjuk, hogy az üvegházhatás erősödése a Föld légkörének melegedésével jár együtt, viszont gyakran szoktuk - helytelenül - azt is említeni, hogy a szélsöségek gyakoribbá és intenzívebbé válnak a melegedő éghajlattal párhuzamosan, noha ez

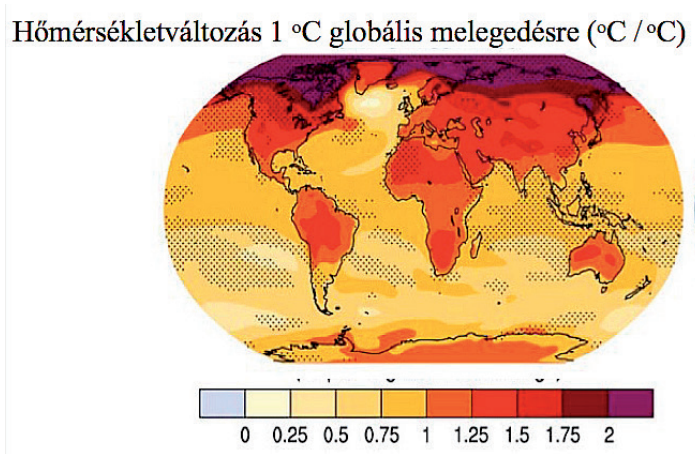

$(\mathrm{K} / \mathrm{K})$

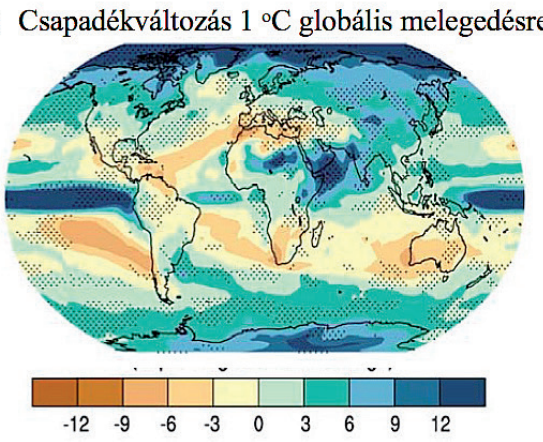

$(\% / \mathrm{K})$

5. ábra. Az évi középhőmérséklet (balra) és a csapadékösszeg (jobbra) megváltozása 42 kapcsolt óceánlégkör modell átlagában, egységnyi $\left(1{ }^{\circ} \mathrm{C}\right)$ globális hömérsékletváltozásra vetítve. A térképek az 1986-2005 közötti időszak modellbeli átlagaihoz képest értendők a 2081-2100 átlagában (forrás: IPCC 2013 12.41. ábra alsó része) 
nem ilyen egyértelmü. Van egy sor olyan szélsőség, amely valóban szaporodik, de vannak olyanok is, amelyek ritkulnak. Szaporodik például az egy-egy nap alatt lehulló csapadék mennyisége a mérsékelt övezet széles sávjában, de egyértelműen ritkul a $-20--25^{\circ} \mathrm{C}$-os hidegek gyakorisága. Ugyanakkor a nyári hőmérsékleti maximum gyakrabban éri el a kritikus $35-40{ }^{\circ} \mathrm{C}$-ot. Ezt már a mostanában megfigyelt adatokon is látjuk a világ nagy részén, így Európában is. A csapadék szélsőségei érdekes kettősséget mutatnak. Majdnem mindenhol szaporodnak az eseti, nagymennyiségű csapadékok, tehát a néhány óra, egy nap alatt lehulló 50-100 milliméter értékű csapadékhozamok, de ugyanakkor az aszályok időtartama is növekszik.

Meg kell állapítanunk, hogy a cirkuláció összetevői közül az északi területeken egyre gyakoribbak az erőteljes mérsékelt övezeti ciklonok, amelyek nagy széllel, heves esőzéssel és jelentős borultsággal járnak. A trópusi ciklonok számával és erősségével kapcsolatban úgy tűnik, hogy míg a nagyon erős örvények száma nő, addig a gyengébb trópusi ciklonok száma nem változik. Mindezekkel szemben jó hír, hogy a mérsékelt övezet örvényei, a tornádók gyakorisága nem mutat növekedést, még az ilyen forgószélnek nagyon kitett amerikai kontinensen sem.

A szélsőségek alakulásának megbízható kimutatását nehezíti, hogy az éghajlati rendszer belső ingásai jó néhány évig is tarthatnak (mint például az írás elején bemutatott globális melegedési hiány). Ezek a belső ingások - minden külső ok nélkül is néhány évig az átlagtól eltérő időjárást tudnak okozni. További probléma a megfigyelt adatok inhomogenitása, azaz a mérési körülmények (pl. településen belüli helyszínek, időpontok, müszerek) változása.

\section{Milyen globális következmények várhatók?}

A globális felmelegedés legegyértelmübb következménye a tengervíz szintjének megemelkedése. Ennek fő oka a hőtágulás; a víznek kismértékben bár, de nagyobb a térfogata akkor, ha emelkedik a hőmérséklete. Körülbelül ezredrész arányban, de hát a tengervíz szintje csaknem 4 kilométer mély, még szerencse, hogy csak a teteje melegszik eleinte. Ezidáig körülbelül 300 méter mélységig tudtuk mindenhol megfigyelni a melegedés okozta térfogatváltozást. A másik ok a szárazföldi jegek olvadása, itt az antarktiszi, a grönlandi és az egyéb kisebb gleccserek olvadásáról lehet szó. Eddig körülbelül 18 centimétert emelkedett a tengervíz szintje, és az elörejelzések szerint legjobb esetben ugyanennyit, rosszabb esetben körülbelül 60 centimétert fog emelkedni a századunk 
végére. A tengerszint emelkedésének a fő következménye az, hogy a víz területet nyer a szárazföldtől, tehát a tengerparti országok, városok vagy sokkal magasabb gátat kénytelenek építeni, vagy arrébb kell költözniük. A magasabb gát építésének van olyan korlátja is, hogy a felszín alatti vizek akkor is feltörnek, ha a tengertől elbarikádozzuk, hiszen alul a gát alatt összeköttetésben van a belső vizekkel. Hátrányos következménye a tengervíz emelkedésének az is, hogy a sós víz betör az édesvízi torkolatokba és ott átalakítja az élővilágot. A tengerszint emelkedésének következménye sajnos a menekültek nagyszámú növekedése. Ha ilyen ütemben változik az éghajlat, mint eddig, akkor 2050-re az ENSZ Menekültügyi Főbiztossága szerint 250-1000 millió ember lesz kénytelen elhagyni a lakóhelyét, lesz éghajlati menekült. Ennek elkerülése érdekében kifejtett tevékenységéért kapott 2007-ben Nobel-békedíjat az ezzel foglalkozó Éghajlatváltozási Kormányközi Testület (IPCC).

Az éghajlatváltozás további következménye a vízellátottság megváltozása. Ez a változás különösen a kontinenseken kritikus. A vízmérleg bevételi oldala a csapadék, ami területileg változó módon és mértékben alakul a melegedés során. A kiadási oldal a párolgás, ami a hőmérséklet emelkedése miatt szinte mindenhol emelkedni fog, tehát veszteségesebbé válik. A csapadékhozam az egyenlítői övben, illetőleg körülbelül az $50^{\circ}$ földrajzi szélességtől északra növekszik éves átlagban. A két terület közötti részen azonban csökken, így éppen ott, ahol jellemzően amúgy is szárazabb az éghajlat, sajnos még szárazabbá válik, míg az Egyenlítő vidékének nedves éghajlata egy kicsit még nedvesebb lesz. A már most is száraz területeken nagyon nagy hátrány a fokozódó vízhiány.

Az éghajlatváltozás mindenképpen alkalmazkodásra kényszeríti a növényeket is. A természetes növénytakaró igazodási képessége gyengébb, mint amilyen gyorsan a változás végbemegy. $1^{\circ} \mathrm{C}$ hőmérsékletemelkedés körülbelül 100 kilométerrel tolja el az övezeteket, és ez az $1{ }^{\circ} \mathrm{C}$-nyi emelkedés még közepes mértékü változás esetén is mintegy 50 év alatt megtörténne. Ilyen gyors alkalmazkodáshoz az erdőségek nem szoktak hozzá; még akkor sem tudnának ilyen gyorsan áthelyeződni, hogy ha korlátlan zöld folyosó állna rendelkezésre, de tudjuk, hogy sok helyen az ember már elgátolta ezeket a zöld folyosókat. Tehát azok az erdőségek, amelyek peremén az éghajlat kedvezőtlenre fordul, el fogják veszíteni eddigi termőképességüket és a versenyben valószínűleg alulmaradnak. A termesztett növények esetében egy kicsit jobb a helyzet, hiszen ezt akár évről évre tudjuk alakítani. A többi évelő növénynek nem annyira hosszú az életciklusa, mint mondjuk az erdőségekben élőknek, de egy alapos, átgondolt növényzettervezést ezek is igényelnek, tehát néhány évtizedre előre látni kell a változást. 
Városaink, településeink sem maradnak érintetlenek az éghajlatváltozástól. A városi éghajlat sajátossága, hogy gyorsabban elnyeli a nedvességet, tehát egy kicsit szárazabb az éghajlata. A háztetők és az útburkolatok fényvisszaverő képessége kisebb, tehát erősebben melegszenek. A házak korlátozzák az átszellőzést, tehát fülledtebb, szerencsétlen esetben szennyezettebb a levegőjük, mint a kisebb településeké. Ez a városi hőmérséklet-különbség, amit városi hőszigethatásnak nevezünk, anticiklonos időjárási helyzetekben a legerőteljesebb. Az éghajlatváltozás folytán bizonyos térségekben az anticiklonosság erősödik, konkrétan Közép- és Dél-Európában minden valószínűség szerint az év téli felében növekedni fog. Már eddig jelentősen több anticiklont tapasztaltunk az utóbbi 50 évben, mint korábban. Tehát azt kell mondanunk, hogy ha egyetlen házzal sem épül több a városainkban, akkor is ez az éghajlati tényező kereszthatásként erősíti a városi hőszigethatást.

Az éghajlatváltozásnak az emberi egészségre is hatása lesz az időjárási helyzetek gyakorisági eloszlásának a megváltozásán keresztül. A legkritikusabb a magas hőmérséklet, ami az elmúlt évtizedekben Európában a legtöbb halálos áldozatot szedte. A nyári hőségriadó már $25^{\circ} \mathrm{C}$-os napi középhőmérsékletnél elrendelhető, a három napon át $27^{\circ} \mathrm{C}$-ot meghaladó értéknél pedig már a harmadfokú készültséget hirdetjük ki. A 2003-as párizsi nagy halálozási epizód - ami egész Európában 70000 fös többlethalálozást okozott - azt a tanulságot hozta, hogy ilyenkor nemcsak a súlyos betegek korai halálozási valószínüsége növekszik, hanem sokan olyanoké is, akik enélkül még évekig élhettek volna. Erre abból következtettek a szakértők, hogy a hőségriadó elmúltával a következő hónapokban nem esett az átlag alá a halálozás.

\section{Hogyan alakul az éghajlatváltozás hazánkban és milyen következményei lehetnek?}

Hazánkban a hőmérséklet emelkedése kicsit gyorsabbnak várható, mint földi átlagban. Ezen belül a nyári időszak melegedése lesz a legerőteljesebb. A téli is jelentős, az átmeneti évszakoké kevésbé meredek. A nyári melegedéshez hozzájárul a mediterrán térségre jellemző, hozzánk is benyúló felhőzetcsökkenés, ami egy cirkulációs változásnak a következménye.

A 2021-2050-es időszakra mintegy $1,5^{\circ} \mathrm{C}$-os az évi középhőmérséklet várható emelkedése 1961-1990-hez képest. A századunk végére 3,5 ${ }^{\circ} \mathrm{C}$-kal emelkedhet a Kárpát-medence hőmérséklete. A csapadék változása előjelében és hatásaiban is negatív, a négy évszak közül csak az őszinek a növekedése mutatkozik a vizsgált időszakban. Ez azért hátrányos, mert főleg a tavaszi és nyári időszakban lenne nagy szükség a csapadékra. 
A globális hőmérséklet emelkedésével párhuzamosan csökken azon időszakok aránya, amikor hó esik a mérsékelt övezet nagy részén, több lesz az esős időszak. A Kárpát-medencében már az elmúlt évtizedekben jelentősen csökkent akár a hótakaró időtartama, akár a havas napok száma. A csapadék és a hőmérséklet összjátékának másik vonatkozása az, hogy a csökkenő vízbevétel és a növekvő párolgás együttesen lecsökkenti a talaj nedvességkészletét, és jelentősen lecsökkenti a lefolyást is. Tehát kevesebb vízzel számolhatunk akár a folyók vízkészletét, akár talajvizeket tekintve, de ugyanez a helyzet a tavak vízkészletével is.

A felmelegedés legnegatívabb következménye tehát Magyarországon elsősorban a kevesebb víz lesz. A zöldtömegképződésnek már ma a víz a legfőbb korlátozó tényezője hazánkban, hiszen hőmérséklet és napfénytartam elegendően áll rendelkezésre. Várható továbbá, hogy ritkábban hullik majd csapadék, de amikor esik, akkor nagyobb mennyiségben, ebből következően növekedni fog az úgynevezett villámárvizek száma.

\section{Amit tennünk kell az éghajlat változásával kapcsolatban}

\section{Van-e remény a változások csökkentésére és mit kell tennünk ezért?}

A világ szén-dioxid-kibocsátását négy tényező határozza meg: a népesség, a jólét, az energiahatékonyság és a szén-dioxid-hatékonyság. (Ehhez hasonlóan más üvegházgázok kibocsátása is ilyen tényezőkre bontható.) A népesség szerepe nyilvánvaló, minél több embert kell ellátni, annál több az összes kibocsátás. A jólétet úgy fogalmazzuk meg, hogy egy ember hány dollárt tud felhasználni. Az energiahatékonyságot úgy fogalmazzuk meg, hogy egy dollár nemzeti össztermék megtermeléséhez mennyi energia szükséges. A szén-dioxid-hatékonyságon pedig azt értjük, hogy egységnyi (pl. $1 \mathrm{MWh}$ ) energia mennyi szén-dioxid kibocsátása árán állítható elő. Tehát e négy tényező között kell keresnünk a megoldást. Ebből a világ népességszámát elég nehéz egyértelmüen csökkenteni, hiszen jelenleg növekvő tendenciát mutat. A jólétet sem érdemes visszafogni, legfeljebb csak nagyon kevés helyen lehet túlzott pazarlásról szólni, a világ nagy részén jogos további felhasználás elébe kell néznünk. Ahol a megoldást kereshetjük, az az energiahatékonyság és a szén-dioxid-hatékonyság, azaz kevesebb energiával termelni a dollárt és kevesebb szén-dioxiddal az energiát. Az alábbiakban ennek lehetőségeit tekintjük át.

A kibocsátás mérséklésének egyik lehetősége az energiatakarékosság. Ezen azt értjük, hogy házainkat szigeteljük, gyártmányainkat pedig kevesebb energia 
felhasználásával állítjuk elő. A másik lehetőség az, hogy a földgáz használata egy kicsit kevesebb szén-dioxidot jelent ugyannyi energiatermelés mellett, mint a kőolajé, és még kevesebbet, mint a kőszéné. Tehát a szükséges energia minél nagyobb hányadát nyerjük földgázból a szénnel szemben, annál kevesebb üvegházhatású gázt bocsátunk ki. Következő lehetőség az erdők telepítése. Napjainkban sajnos még pusztulnak az erdők, évente elvész egy belgiumnyi terület, de ha ezt sikerül visszafordítanunk, az segít a szén megkötésében. Van egy olyan mesterséges széndioxid-megkötési közelítés is, hogy a kibocsátott szén-dioxidot nem engedjük ki a levegőbe, hanem visszatartjuk, és elhelyezzük valamiképpen a felszín alatt. Kérdés, hogy megoldást jelentenek-e az atomerőmüvek, mert bár azok kevés szén-dioxidot termelnek, sok egyéb más környezeti problémájuk van. A nukleáris energia termelésének stagnálásából azonban úgy tűnik, hogy az atomenergia sem teljes megoldás.

Az éghajlatváltozás mérséklésében nagy reményt füzhetünk a megújuló energiaforrások (nap-, szél-, víz-, geotermikus energia, földhő, bioenergia és az óceánok hullám- és árapályenergiája) használatához. Ezek nagy része alig bocsát ki szén-dioxidot, legfeljebb az eszközök megtermelése, szállítása jelent üvegházgáz-erősödést. A napenergia mennyisége például néhányszorosan fedezni tudná az egész Föld energia szükségletét is, de ehhez nagyon nagy területeket kellene napelemekkel borítani, ami végül is nem reális elképzelés. A szélenergia is nagyon sok helyen jelentős mennyiségben rendelkezésre áll. Minél magasabbra helyezzük a lapátot, amit a szél forgat, annál több energiára tehetünk szert. A bioenergia megítélése néha vitatott, ugyanis sajnos bioenergiának számít az is, amikor egyszerủen elégetjük a tűzifát vagy a bútorfát. Másik probléma, hogy élelmiszertermelésre kellene hasznosítanunk a Föld területének nagy részét. A vízenergia számos térségben korlátozott, például Magyarországon a folyók kis esése miatt kevés a kiaknázható vízenergia. Az óceáni energia termelése jelenlegi nagyságrendekkel elmarad más megújuló formákkal szemben, aminek az energia kinyerése és felhasználása közötti távolság a fö oka.

Hogyan tudnánk mi magunk takarékoskodni az energiával? Hogyan tudnánk kevesebb szén-dioxidot kibocsátani? Az energiatakarékosság azt jelenti, hogy kevesebbet fizessünk az energiáért és azt a pénzt másra használjuk fel, egyszersmind segítve a Föld éghajlatának a megkímélését és más környezetszennyezö tevékenységek visszaszorítását is. Amikor a lakásban vagyunk, megtehetjük, hogy egy fokkal csökkentjük a hőmérsékletet - pl. nem $24^{\circ} \mathrm{C}$-ra, hanem $23^{\circ} \mathrm{C}$-ra fütjük fel -, és máris $6 \%$-kal csökkentjük az erre fordított összeget. Ha lefedjük a főzéskor konyhában az edényünket, azzal is néhány 
százalékot megtakarítunk. Ha kuktában fözünk, akkor alacsonyabb hőmérsékleten jön létre a forrás, ami az ételt megpuhítja. Amikor a fürdőszobában zuhanyozunk, sokkal kevesebb vízzel meg tudunk fürdeni, mintha teljes kádat megtöltenénk. Érdemes az ablakokat szigetelni és az autóval alacsonyabb sebességgel haladni. Ha megtehetjük, hogy ne siessünk, akkor óránként 80 kilométerrel haladva 30\%-kal kevesebb üzemanyagot égetünk el, mintha végig $120 \mathrm{~km} / \mathrm{h}$ sebességgel haladnánk. A fenti példák mindegyike olyan, ami anyagi haszonnal is jár!

Az alábbiakban két diagramot mutatunk be (6. ábra). Elsőként lássuk, hogyan alakult a szén-dioxid kibocsátása 2016-ig, illetve becsült értékként 2017-ben. Látható, hogy a nem mezőgazdasági kibocsátás néhány évi stagnálás után ismét nőtt 2017ben, méghozzá évi mintegy 2\%-kal. A légköri szén-dioxid-koncentráció növekedése ugyanakkor folyamatos, mivel a stagnáló évek kibocsátása is jelentősen meghaladja azt a szintet, amit az óceánok és a szárazföldek még semlegesíteni tudnak. (Meg kell ugyanakkor jegyeznünk, hogy e szférák semlegesítő képessége a mai kibocsátások mellett ekkora, kisebb kibocsátás esetén szerényebb lehet.) Minél jobbam megközelítjük hosszabb távon a nulla kibocsátást, annál biztosabb, hogy a koncentrációk nem nőnek tovább, ezáltal már csak az óceáni hőelnyelés miatti „büntető melegedés” emeli a hőmérsékletet. (Ezen azt értjük, hogy már stagnáló koncentrációk mellett még mindig emelkedni fog a légkör hőmérséklete, mert a megelőző évtizedek növekvő kibocsátása miatt keletkezett hőtöbblet - amely eleinte csak az óceánokat melegítette - egy részét az óceán késleltetve adja át a légkörnek.)

\section{Mit ígér a Párizsi klímamegállapodás és mire elég ez?}

A végső feladat a melegedés lefékezése, majd megállítása, amihez a légkör állandó összetétele szükséges. Ez nem kevesebbet követel, mint azt, hogy ne bocsássunk ki több üvegházgázt, mint amennyit a földi szférák, elsősorban az óceánok mélye és a bioszféra el tud nyelni. A szén-dioxid esetében az óceáni mészkőpadozat és a növényi fotoszintézis képes erre. Ez az elnyelö képesség 60-80\%-kal kisebb, mint a mai kibocsátás, vagyis ennyivel kell lecsökkenteni a kibocsátást ahhoz, hogy ne növekedjen a gázok koncentrációja!

A klímapolitika régóta a $2{ }^{\circ} \mathrm{C}$-os küszöböt szorgalmazza. Ennek egyik oka, hogy akkor biztosabban sikerül a $3^{\circ} \mathrm{C}$, a másik ok a tengerszint folyamatos emelkedése, mint elkerülendő probléma. A Párizsi megállapodás (2015) lehetőség szerint $1,5^{\circ} \mathrm{C}$-hoz közeli stabilitást tűzne ki célul az ipari forradalom előtti értékhez képest. E cél realitásának 

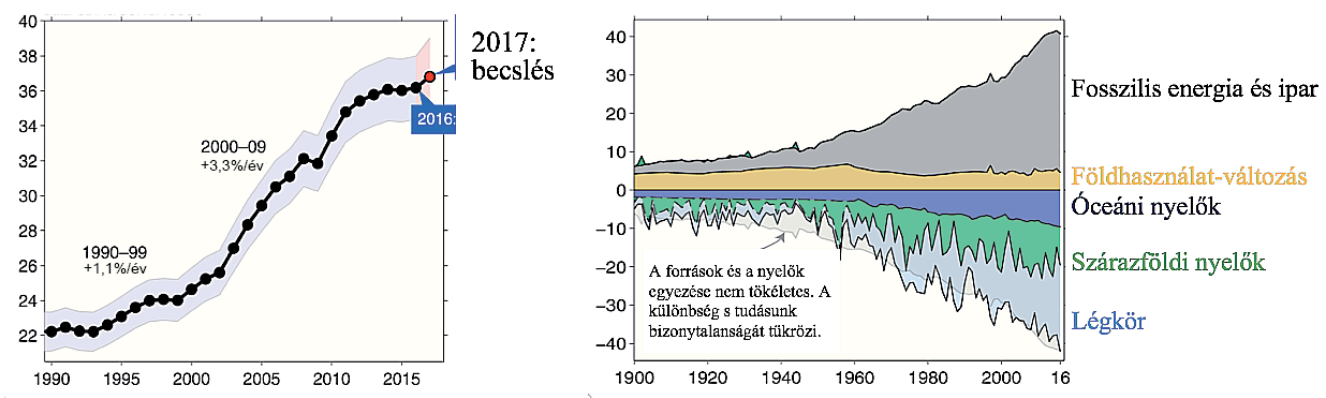

6. ábra. A fosszilis energiahasználat és a cementgyártás miatti $\mathrm{CO}_{2}$-kibocsátás ( $\mathrm{GtCO}_{2} / e ́ v$ : balra), valamint az összes kibocsátás és annak megoszlása a földi szférák között (GtCO/ /év: jobbra) (Le Quéré et al. 2017). A jobb oldali ábrán a nyelök összege nem mindig adja ki a forrásokét, vagyis ismereteink pontossága korlátozott.

megítéléséhez vegyük figyelembe, hogy egyrészt már eddig végbement földi átlagban 1,0 ${ }^{\circ} \mathrm{C}$-os melegedés, másrészt, hogy a légkör összetételének állandósulása után még 0,3-0,4 ${ }^{\circ} \mathrm{C}$-os, ún. „büntető melegedés” következik be majd amiatt, hogy a nagy hőkapacitású óceánok, amelyek nem engedték egészében érvényre jutni az üvegházhatás erősödését, később tovább fogják melegíteni a felszínközeli levegőt. E két értéket összeadva már majdnem $1,5{ }^{\circ} \mathrm{C}$-nál tartunk!

A Párizsi megállapodást az egyes országok vezetői számára a Föld napjától, 2016. április 22-től számítva egy évig tartották nyitva az országonkénti ratifikáció (nemzeti jogrendbe iktatás) lebonyolítására, és azt követően aláírásra az ENSZ New York-i székhelyén. A megállapodás az országonként tett felajánlásokkal együtt legkorábban 2020. január 1-jén válik majd érvényessé, amihez legalább 55 ország csatlakozása szükséges, és az, hogy az általuk képviselt együttes kibocsátás is eléri az 55\%-ot. Szerencsés módon e számokat 2016. október 5-re elértük, így a Párizsi klímamegállapodás egy hónappal később, 2016. november 4-én életbe lépett.

Az egyes országok eddigi önkéntes vállalásai azonban nem elegendők a globális melegedés $2{ }^{\circ} \mathrm{C}$ alatt tartásához. A szerény eredmény fő oka, hogy egyes nagy kibocsátók csekély vállalásokat tettek, pl. Kína csak azt, hogy 2030-tól nem növeli a kibocsátást. Hazánk az EU minden országával azonos, 40\%-os csökkentést vállalt 2030-ra. Az A merikai Egyesült Államok 26-28 \%-os csökkenést vállalt 2025-re a 2005-ös állapothoz képest. Kína és az Amerikai Egyesült Államok összevetéséhez fontos tudni, hogy bár abszolút mértékben Kína kibocsátása egyértelmüen meghaladja az USA-ét, de egy före vetítve egy kínai polgár csak felét bocsátja ki az amerikai átlagnak. (Azóta az Amerikai 
Egyesült Államok elnöke bejelentette, hogy 2020-tól országa kilép a megállapodásból.) A Párizsi megállapodás felülvizsgálatára és lehetőség szerint újabb, a mostaninál még nagyobb vállalások rendezett megtételére 2023-ban nyílik majd lehetőség.

\section{Vannak-e olyan geomérnöki megoldások, amelyekkel tovább enyhíthetö a melegedés?}

A legutóbbi IPCC Jelentés gyüjtötte össze először azokat a geomérnöki megoldásokat, amelyek a kibocsátások szükséges korlátozása mellett további lehetőségeket kínálnak a felmelegedés lassítására. Az elképzelések két nagy csoportja a szén-dioxid elnyelésének erősítése, illetve a bolygó fényvisszaverő képességének az erősítése.

Az első csoportban olyan elképzelések sorakoznak, hogy alkálifémek és vas tengerbe juttatásával erősítsük az óceáni moszatokat, fokozva ezzel fotoszintézisüket, azaz a szén-dioxid-elnyelésüket. Technikailag megoldható a keletkező szén-dioxid kivonása a légkörből, illetve olyan növények elötérbe helyezése, amelyeknek nagyobb a zöldtömege, de máskülönben ugyanazt nyújtják, mint szerényebben fotoszintetizáló társaik. Végül jó megoldás lenne minél nagyobb területek erdősítése.

A második csoportba az elvben legegyszerűbb megoldások tartoznak. Például olyan óriási tükrök felszerelése a felszínen vagy a világürben, amelyek sok napenergiát visszavernek. Felmerülhet a napsugarakat szóró aeroszolok feljuttatása a sztratoszférába (mert lejjebb gyorsan kimosódna), illetve a felhők szerkezetébe való beavatkozás szulfátsók bejuttatásával, hogy így erősítsük a korábban említett közvetett aeroszolhatást. Érdekes ötlet a vízfelszínek buborékosítása, mert az ilyen felszín több napfényt ver vissza, mint a sima vízfelszín. Itt is érdemes a célhoz alkalmas olyan növényeket elötérbe helyezni, amelyek fényvisszaverő képessége nagyobb a többinél, de egyébként ugyanazt a használati értéket nyújtják (például a lombos erdők jóval több fényt vernek vissza, mint a fenyőerdők). A sor végén itt is egy már ismert lehetőség, a háztetők és útburkolatok világosabb színű kivitelezése említhető, amit gyakorta javasolnak a városi hőszigethatás tompítására.

Bár egyes fenti megoldásokra már akadnak kísérleti jellegü példák, mégis azt kell mondanunk, egyrészt az egyes elképzelések müszaki és gazdasági kivitelezhetősége terén nincs elegendő ismeretünk ahhoz, hogy ezek lehetőségek felmerüljenek a klímavédelmi tárgyalások során, másrészt jelen előkészítettségében azt sem tudjuk a legtöbb elképzelésről megállapítani, hogy nincsenek-e olyan környezeti következményeik, amiket jobb lenne elkerülni. 


\section{Mit jelent az alkalmazkodás és mikor kell hozzákezdeni?}

Az éghajlatváltozáshoz történő alkalmazkodáson azt a tevékenységet értjük, amelynek célja a változásból fakadó hátrányok mérséklése és az esetleges előnyök felhasználása. Az alkalmazkodáshoz a legtöbb esetben egy-két évtized elegendö, kivéve talán a hosszú ciklusú erdők telepítését. Az éghajlat változásaihoz való alkalmazkodás lényege, hogy már ma olyan épületek és más műtárgyak szülessenek, amelyek megfelelnek az előrevetített jövőbeli éghajlatnak. A példák közül csak néhányat említve: szárazságtűrő növények, nagy esőt is elvezető csatornák, a csapadék későbbi felhasználását lehetővé tevő tározók, a kevesebb hó- és zúzmaraterhelésnek megfelelő háztetők és elektromos vezetékek, kisebb hőigényre, de fokozottabb hütésre tervezett fütő és hủtő alkalmatosságok stb.

A kibocsátás mérséklésének mindenütt univerzális lehetőségeivel szemben az alkalmazkodás országonként, sőt térségenként, településenként is más-más feladatokat és megvalósítási lehetőségeket jelent. Ehhez ismerni kell az adott térség sajátosságait és az ott valószínüsíthető éghajlatváltozást. Az EEA 2017. évi jelentése minden, a tudományos irodalom által megállapított, tapasztalt és elörejelzett hatást magába foglalt (7. ábra, 2. táblázat). Európa egyes térségeit hét típusba sorolja és összesíti, hogy hol milyen hatásokra kell számítani, azaz mihez érdemes alkalmazkodni. Megjegyezzük, hogy az időjárás szélsőségeihez is fontos alkalmazkodni, de ez csak részben esik egybe az évtizedes éghajlatváltozáshoz való alkalmazkodás feladataival.

\section{Irodalom}

EEA 2017: Climate change, impacts and vulnerability in Europe 2016. An indicator-based report. European Environment Agency. 419 p.

Field, C. B. - Barros, V. R. - Dokken, D. J. - Mach, K. J. - Mastrandrea, M. D. - Bilir, T. E. Chatterjee, M. - Ebi, K. L. - Estrada, Y. O. - Genova, R. C. - Girma, B. - Kissel, E. S. - Levy, A. N. - MacCracken, S. - Mastrandrea, P. R. - White, L. L. (szerk): IPCC 2014 - Climate Change 2014: Impacts, adaptation, and vulnerability. Part A: Global and sectoral aspects. Contribution of Working Group II to the Fifth Assessment Report of the Intergovernmental Panel on Climate Change. - Cambridge University Press, Cambridge \& New York. 1132 p.

Lenton, T. M. - Held, H. - Kriegler, E. - Hall, J. W. - Lucht, W. - Rahmstorf, S. - Schellnhuber, H. J. 2008.: Inaugural article: Tipping elements in the Earth's climate system. Proceedings of the National Academy of Sciences 105. 6. 1786 p. https://doi:10.1073/pnas.0705414105

LE Quéré, C. et al. (76 társszerzővel) 2017: Global carbon budget 2017. - Earth Syst. Sci. Data Discuss. https://doi.org/10.5194/essd-2017-123. 
MikA J. 2011: Éghajlatváltozás, hatások, válaszadás. Főiskolai jegyzet. Eger, 128 p. http://www.tankonyvtar. hu/hu/tartalom/tamop425/0038_foldrajz_MikaJanos-eghajlat-HU/ch01.html

Mika J. 2014: Szünetelö melegedés - kihívások és következtetések az IPCC jelentéseiben (2013-2014). - In: Sansumné Molnár J.-Siskáné Szilasi B.-Dobos E. (szerk.): VII. Magyar Földrajzi Konferencia. pp. 421-428. http://www.uni-miskolc.hu/ foldrajz/Foldrajzikonferencia/magyar_foldrajzi_konferencia.html

Párizsi Megállapodás 2015. http://unfccc.int/files/essential_background/convention/application/pdf/english_ paris_agreement.pdf

Solomon, S. - Qin, D. - Manning, M. - Chen, Z. - Marquis, M. - Averyt, K. B. - Tignor, M. Miller, H. L. (szerk.): IPCC 2007 - Climate change 2007: the physical science basis. Contribution of Working Group I to the Fourth Assessment Report of the Intergovernmental Panel on Climate Change. - Cambridge University Press, Cambridge \& New York.

Stocker, T. F. - Qin, D. - Plattiner, G.-K. - Tignor, M. - Allen, S. K. - Boschung, J. - Nauels, A. - XiA, Y. - BeX, V. - Midgley P. M. (szerk.): IPCC 2013 - Climate Change 2013: the physical science basis. Contribution of Working Group I to the Fifth Assessment Report of the Intergovernmental Panel on Climate Change. - Cambridge University Press, Cambridge \& New York. 1535 p.

http://berkeleyearth.org/global-temperatures-2017/

http://www.bom.gov.au/info/climate/change/gallery/1.shtml)

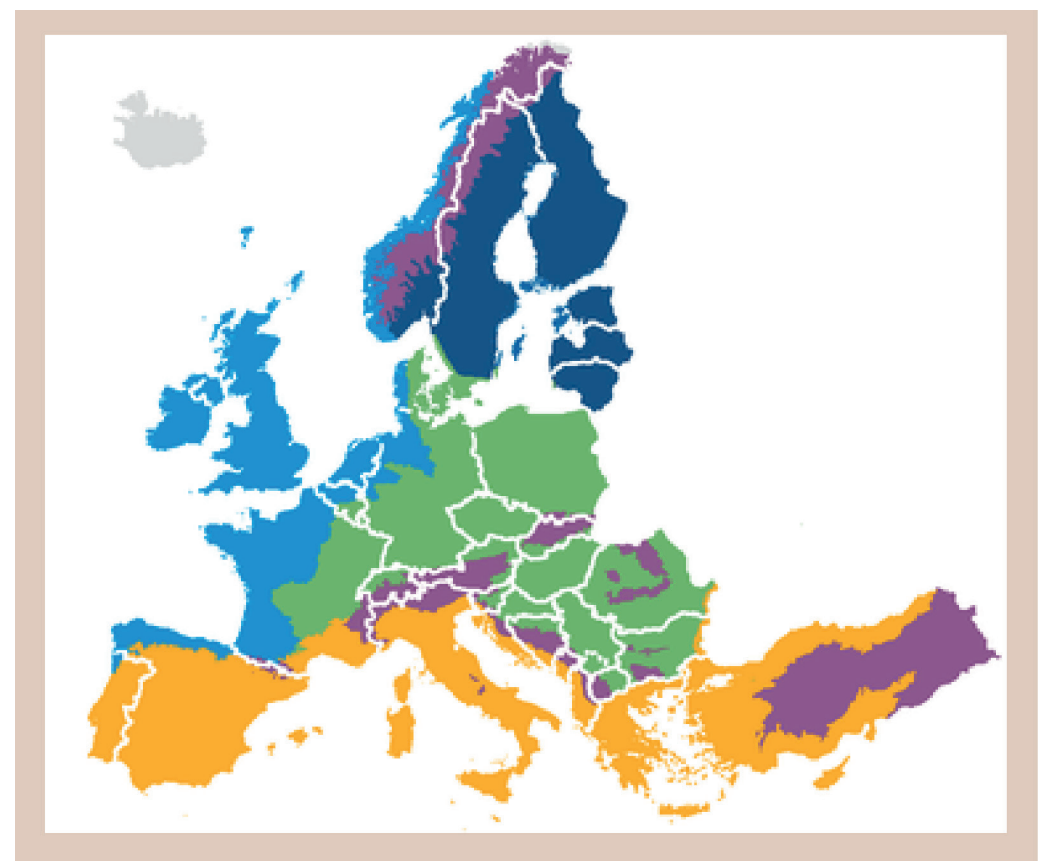

7. ábra. Európa hét föbb régiója, amelyben az éghajlati változások hatásai megjelennek (2. táblázat) 


\section{1. Északi sarkkör}

A hőmérséklet emelkedése messze meghaladja a globális átlagot

A tengeri jéggel borított terület csökken

A grönlandi jégtakaró visszahúzódik

Az örökfagy (permafroszt) kiterjedése csökken

A biodiverzitás csökkenésének veszélye nő

Új lehetőség nyílik természetes erőforrások kiaknázására és tengeri szállitásra

A helyi lakosok megélhetése veszélybe kerül

\section{Tengerparti régiók, tengerek}

A tengerszint megemelkedik

A tenger felszíni hőmérséklete megemelkedik

A tengervíz savasodik

A tengeri élővilág északra vándorol

Új kockázatok és némi új lehetőségek nyílnak a halászat számára

Fitoplankton-együttesek megváltoznak

Megnövekedett számú tengeri holtterületek jönnek létre

Vízzel terjedő betegségek veszélye fokozódik

\section{Mediterrán régió}

Fokozottan szélsőséges hőmérséklet alakul ki

A csapadék- és vízmennyiség csökken

A szárazság veszélye fokozódik

A biodiverzitás csökkenésének veszélye nő

Erdőtüzek veszélye fokozódik

Erősödő verseny alakul ki a vízhasználók között

\section{Atlanti-régió}

Nagy intenzitású csapadékesemények gyakoribbá válnak

Folyók vízhozama növekszik

A folyami és tengerparti áradások veszélye fokozódik

Súlyosabb károkat okozó téli viharok lépnek fel

A fütés energiaigénye csökken

Számos éghajlattal kapcsolatos veszély fokozódik

\section{Boreális régió}

Nagy intenzitású csapadékesemények gyakoribbá válnak

A hó mennyisége, a tavak és folyók jégborítottsága csökken

A csapadék mennyisége és folyók vízhozama nő

Az erdősülés fokozódik, az erdei kártevők elszaporodnak

Súlyosabb károkat okozó téli viharok lépnek fel

A terméshozamok nőnek 


\section{Boreális régió}

A fütés energiaigénye csökken

A potenciális vízenergia nő

A nyári turizmus megnő

A mezőgazdaság vízigénye fokozódik

A terméshozamok csökkennek

Az állattenyésztés kockázatosabbá válik

Nő a halálozási ráta a hőhullámok idején

A járványok élettere megnövekszik

Az energiatermelés lehetőségei szükülnek

A hútési energia iránti igények növekednek

\section{Hegységi régiók}

Az európai átlagnál erősebben melegednek

A gleccserek kiterjedése és térfogata csökken

A növények és állatok magasabb régiókba vándorolnak

Fajok kihalásának veszélye fokozódik

Az erdei kártevők elszaporodnak

Hegyomlások, földcsuszamlások veszélye nő

A vízenergia adottságai változnak

A síturizmus csökken

\section{Kontinentális régió}

A hőmérsékleti szélsőségek gyakoribbá válnak

A nyári csapadék csökken

A folyók áradásának veszélye fokozódik

Erdőtüzek veszélye fokozódik

Erdők gazdasági értéke csökken

A hütéstechnológia energiaigénye megnövekszik

A nyári turizmus csökken, a turizmus más évszakokban potenciálisan nő

Számos éghajlati veszély fokozódik

A legtöbb iparágat negatív hatások érik

Az Európán kívüli éghajlatváltozás káros hatásai fokozott veszélyt jelentenek

2. táblázat. A legfontosabb éghajlati változások és hatások Európa hét föbb régiójában (EEA, 2017: MAP ES1) 